\title{
CARBON SOURCES AND TROPHIC POSITION OF THE MAIN SPECIES OF FISHES OF BAÍA RIVER, PARANÁ RIVER FLOODPLAIN, BRAZIL
}

\author{
MANETTA, G. I., ${ }^{1}$ BENEDITO-CECILIO, E. ${ }^{1}$ and MARTINELLI, M. ${ }^{2}$ \\ 'PEA, NUPELIA, Universidade Estadual de Maringá, Av. Colombo, 5790, CEP 87020-900, Maringá, Brazil \\ ${ }^{2}$ Centro de Energia Nuclear (CENA), Universidade Estadual de São Paulo-USP, Piracicaba, Brazil \\ Correspondence to: Gislaine Iachstel Manetta, Rua Cuiabá, 342, Jardim Cidade Nova, CEP 97120-030, Maringá, \\ PR, Brazil, e-mail: eva@ nupelia.uem.br \\ Received Juny 12, 2002 - Accepted July 8, 2002 - Distributed May 31, 2003
}

(With 2 figures)

\begin{abstract}
In order to verify the carbon source and trophic position of the main species of fishes, of the Paraná River floodplain, we analysed the proportion of stable carbon $\left(\delta^{13} \mathrm{C}\right)$ and nitrogen $\left(\delta^{15} \mathrm{~N}\right)$ isotopes in muscle of fishes sampled in the rainy season. We analyzed adult individuals of Loricariichthys platymetopon, Schizodon borellii, Leporinus lacustris, Auchenipterus osteomystax, Iheringichthys labrosus, Leporinus friderici, and Serrasalmus marginatus. These data were compared with the results obtained by the analyzing stomach contents. The primary producers found in the Baía River were the $\mathrm{C}_{3}$ plants (riparian vegetation, macrophytes, periphyton, and phytoplankton) and the $\mathrm{C}_{4}$ plants (macrophytes). The results of the contribution analysis revealed that the carbon used by the species was derived from $\mathrm{C}_{3}$ plants. According to the trophic position estimates (diet and $\delta^{15} \mathrm{~N}$ ), the species primarily consumed Loricariichthys platymetopon, Schizodon borellii, Leporinus lacustris, and Leporinus friderici and, secondarily Auchenipterus osteomystax, Iheringichthys labrosus, and Serrasalmus marginatus. There was no significant difference between the two methods utilized.
\end{abstract}

Key words: Baía River, fishes, stable isotope, trophic position, energy source.

\section{RESUMO}

Fontes de carbono e posição trófica das principais espécies de peixes do rio Baía, planície de inundação do rio Paraná

Com o objetivo de verificar a fonte de carbono e a posição trófica das principais espécies de peixe da planície de inundação do rio Paraná, foram analisadas as proporções de isótopos estáveis de carbono $\left(\delta^{13} \mathrm{C}\right)$ e nitrogênio $\left(\delta^{15} \mathrm{~N}\right)$ em músculos de peixes amostrados no período de chuvas. Foram analisados indivíduos adultos das espécies Loricariichthys platymetopon, Schizodon borellii, Leporinus lacustris, Auchenipterus osteomystax, Iheringichthys labrosus, Leporinus friderici e Serrasalmus marginatus. e dados foram comparados com os resultados da análise do conteúdo estomacal. Os produtores primários existentes no subsistema Baía foram as plantas $C_{3}$ (vegetação ripária, macrófitas, perifíton e fitoplâncton) e as plantas $\mathrm{C}_{4}$ (macrófitas). O resultado da análise de contribuição revelou que o carbono utilizado pelas espécies foi proveniente das plantas $\mathrm{C}_{3}$. Conforme as estimativas da posição trófica (dieta e $\delta^{15} \mathrm{~N}$ ), as espécies foram categorizadas como consumidoras primárias (Loricariichthys platymetopon, Schizodon borellii, Leporinus lacustris e Leporinus friderici) e consumidoras secundárias (Auchenipterus osteomystax, Iheringichthys labrosus e Serrasalmus marginatus). Não houve diferença significativa entre os dois métodos utilizados.

Palavras-chave: rio Baía, peixes, isótopos estáveis, posição trófica, fonte de energia. 


\section{INTRODUCTION}

Primary production in the Paraná River floodplain is supported by three main plant groups: $\mathrm{C}_{3}, \mathrm{C}_{4}$, and CAM (Lopes, 2001). The $\mathrm{C}_{3}$ plant group is constituted by aquatic macrophytes, phytoplankton, periphyton, and riparian vegetation. The $\mathrm{C}_{4}$ plant group is constituted only by some species of aquatic macrophytes, which occur sporadically, while the CAM plant group is abundantly distributed all over the floodplain, although represented by few species (Lopes, 2001).

Nowadays, the combined use of stable isotopes contributes in identifying the original organic nutrient sources in complex food webs (Jennings et al., 1997; Magnusson et al., 1999; Thomas \& Cahoon, 1993), which have been directly related to assimilation, the natural proportions of stable isotopes in animal tissue reflect diet in a predictable way (De Niro \& Epstein, 1978; Fry, 1988). Thus, according to the isotopic composition of the consumers' tissues, an item assimilated among those ingested is precisely indicated (Fry \& Arnold, 1982).

As a result of fractionation during food assimilation, the ${ }^{15} \mathrm{~N}$ isotope becomes enriched in relation to the ${ }^{14} \mathrm{~N}$ (De Niro \& Epstein, 1981). Thus, the $\delta^{15} \mathrm{~N}$ ratio increases from 3 to $4 \%$ o for each successive trophic level. On the other hand, ${ }^{13} \mathrm{C}$ becomes enriched in ${ }^{12} \mathrm{C}$ with assimilation of food by about $1 \%$ (Fry \& Sherr, 1984). Through the isotopic signature of the consumer, it is possible to identify the origin of the autotrophic carbon, while the trophic chain structure can be drawn from the nitrogen isotopes. The $\delta^{15} \mathrm{~N}$ changes consistently along the food web, allowing inferences about the trophic position of consumers.

The subsystems in the Baía River floodplain the present all the plant groups, affording a rich opportunity for analyzing the food web of the main species of fish, belonging to different trophic groups.

The more abundant fish species in this subsystem, grouped by trophic categories are: Loricariichthys platymetopon, detritivorous/iliophagous; Schizodon borellii, herbivorous; Leporinus lacustris, herbivorous/ omnivorous; Auchenipterus osteomystax, insectivorous/ carnivorous; Iheringichthys labrosus, bentophagous; Leporinus friderici, omnivorous; and Serrasalmus marginatus, piscivorous (Peretti, 2001). The diversified diet of the main species presumes the use of energy from more than one producer; it has been, however, difficult to evaluate which of them forms the energetic chain base.

Thus, the present work, using carbon $\left(\delta^{13} \mathrm{C}\right)$ and nitrogen $\left(\delta^{15} \mathrm{~N}\right)$ stable isotopes analysis, proposed to establish if (1) the carbon source maintaining the biomass of the main fish species differs for each trophic group analyzed and if (2) the trophic position of the fish species, identified according to the dietary data, differs from the estimate made through the $\delta^{15} \mathrm{~N}$.

\section{MATERIAL AND METHODS}

The study was developed in the Upper Paraná River floodplain, located in the lower stretch in the Baía River subsystem, in the State of Mato Grosso do Sul. The Baía Channel (224’26.94’'S; 5313'29.34'W) extends from the confluence of the Baía River and Corutuba stretch to the Paraná River. Its depth averages $2.0 \mathrm{~m}$ and its marginal vegetation is pastureland. The Baía River (22 43'23.16”'S; $\left.53^{\circ} 17^{\prime} 25.5^{\prime} \mathrm{W}\right)$ presents variable width, and depth averaging $3.2 \mathrm{~m}$.

The Baía subsystem presents numerous lagoons along its course and its entirety is strongly controlled by the Paraná River (Fig. 1). Samples were collected in the channel and in the Baía River in February 2000 and February 2001 (the rainy season). In this period of the year, the water level increases and, consequently, there is a greater contribution from allochthonous sources to the aquatic food webs.

Fish were sampled with different size gill nets. From each adult individual, we extracted a sample of muscle from near the base of dorsal fin insertion. The species and the number of individuals analyzed were: Auchenipterus osteomystax (Spix, 1829) $(\mathrm{n}=$ 9); Serrasalmus marginatus, Valenciennes, 1847 ( $\mathrm{n}=$ 9); Iheringichthys labrosus (Kroeyer, 1874) $(\mathrm{n}=$ 9); Leporinus lacustre, Campos, 1945 ( $\mathrm{n}=12)$; Loricariichthys platymetopon, Isbrucker \& Nijssem, $1979(\mathrm{n}=10)$; Leporinus friderici (Bloch, 1794) $(\mathrm{n}=$ 7); Schizodon borellii (Boulenger, 1895) $(n=6)$.

Samples from allochthonous sources were constituted of 52 plants of riparian vegetation with $\mathrm{a} \mathrm{C}_{3}$ photosynthetical pathway, while the autochthonous sources corresponded to 95 aquatic macrophytes and 42 periphyton with a $\mathrm{C}_{3}$ photosynthetical pathway, and 39 with a $\mathrm{C}_{4}$ photosynthetical pathway, besides 40 samples of particulated organic carbon (POC). 


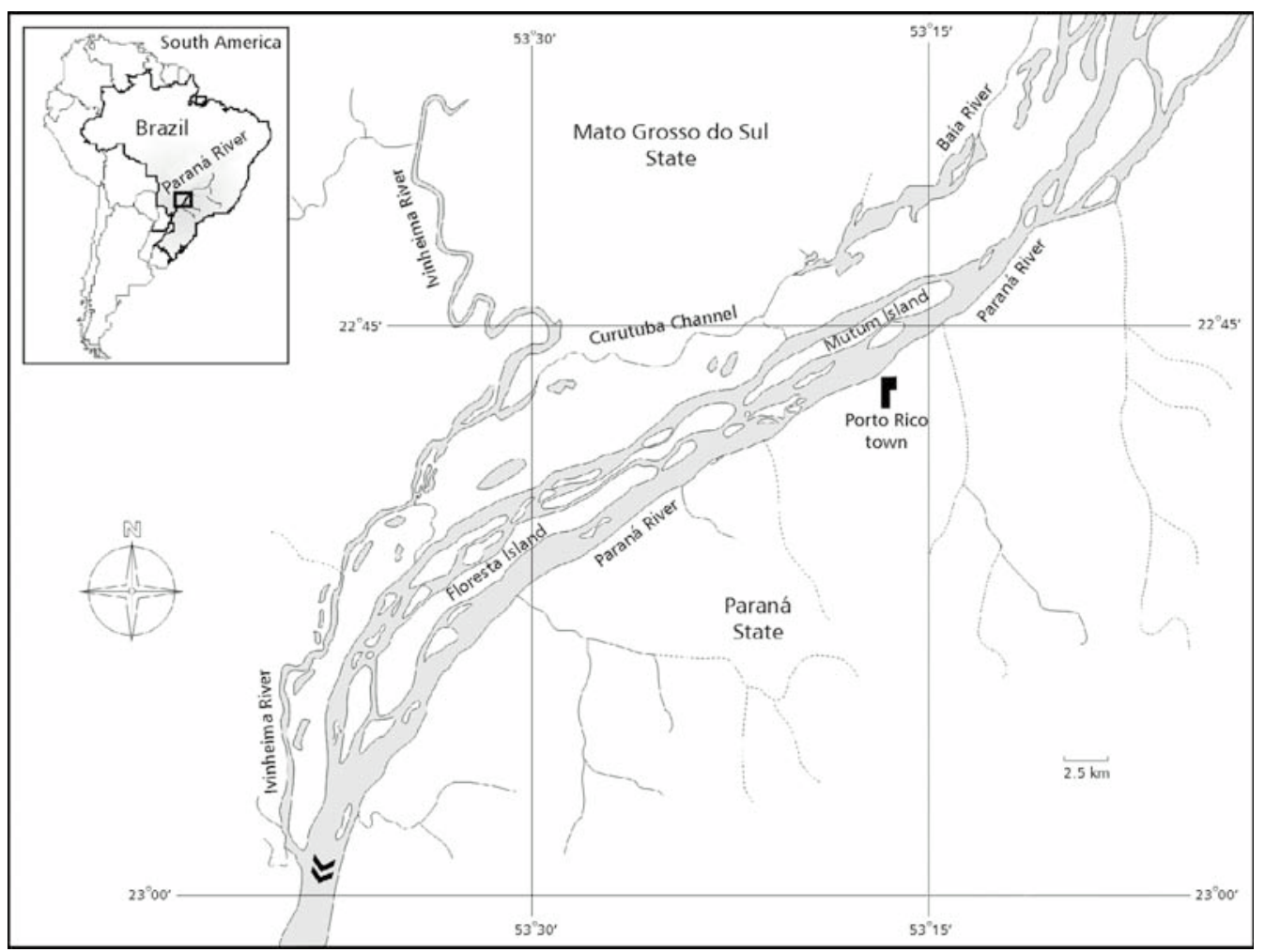

Fig. 1 - Localization of the Baía River in the Paraná River floodplain.

The isotopic values of phytoplankton were determined through the zooplankton, considering a $1 \%$ fractionation for a trophic level of $\delta^{13} \mathrm{C}$. The zooplankton, cladocerous, and filtrator copepods were sampled with a zooplankton net (Lopes, 2001).

After being dried in an oven $\left(60^{\circ} \mathrm{C}\right)$, the samples were sent to the Centro de Energia Nuclear na Agricultura (CENA), in Piracicaba, São Paulo, for carbon $\left(\delta^{13} \mathrm{C}\right)$ and nitrogen $\left(\delta^{15} \mathrm{~N}\right)$ isotopic value analysis.

For the Baía subsystem, the carbon mean isotopic value of samples from $\mathrm{C}_{4}$ plants (aquatic macrophytes) was $-12.6 \%$, and from $\mathrm{C}_{3}$ plants (periphyton, aquatic macrophytes, and riparian vegetation) it was $-29.4 \%$. The primary producer group with the most negative $\delta^{13} \mathrm{C}$ value (phytoplankton) was used to estimate the maximum contribution from $\mathrm{C}_{4}$ plants to the biomass of the fish species, while the most positive (aquatic macrophytes) was used to determine the minimum contribution expected (Forsberg et al., 1993):

$$
\% \mathrm{C}_{4}=\left[1-\frac{\delta^{13} \mathrm{C}_{\mathrm{fish}}-\delta^{13} \mathrm{C}_{\mathrm{C} 4}}{\delta^{13} \mathrm{C}_{\mathrm{C} 3}-\delta^{13} \mathrm{C}_{\mathrm{C} 4}}\right] \times 100
$$

where $\delta^{13} \mathrm{C}$ fish is the carbon mean isotopic value of each specie; $\delta^{13} \mathrm{C}_{\mathrm{C} 4}$ and $\delta^{13} \mathrm{C}_{\mathrm{C} 3}$ are the $\delta^{13} \mathrm{C}$ mean values from $\mathrm{C}_{3}$ and $\mathrm{C}_{4}$ plants, respectively.

For the trophic position estimate through $\delta^{15} \mathrm{~N}$ isotopic values $\left(\mathrm{PT}_{\delta 15 \mathrm{~N}}\right)$ and dietary $\left(\mathrm{PTM}_{\mathrm{d}}\right)$, we used the expression proposed by Vander-Zanden et al. (1997):

$$
\mathrm{PT}_{\delta 15 \mathrm{~N}}=\left(\left(\delta^{15} \mathrm{~N}_{\text {fish }}-\delta^{15} \mathrm{~N}_{\text {source }}\right) / 3.4\right)+1
$$

where, $\delta^{15} \mathrm{~N}_{\text {fish }}$ is the $\delta^{15} \mathrm{~N}$ mean value of each species; $\delta^{15} \mathrm{~N}_{\text {source }}$ is the $\delta^{15} \mathrm{~N}$ mean value of allochthonous and autochthonous sources. The 3.4 and 1 values represent the fractionation for the trophic level (De Niro \& Epstein, 1981; Minagawa \& Wada, 1984) and one level above the producers, respectively;

$$
\mathrm{PTM}_{\mathrm{d}}=\Sigma\left(\mathrm{C}_{\mathrm{i}} * \mathrm{~T}_{\mathrm{i}}\right)+1
$$


where $\mathrm{C}_{\mathrm{i}}$ represents the contribution in percentage of food item $i$; $T_{i}$ is the trophic position of food item $i$.

The proportion of food items constituting the diet of each species was taken from Peretti (2001), while the estimated trophic position values for the preys was 1.0 (producers), 2.0 (herbivorous), 2.5 (omnivorous), and 3.0 (carnivorous), according to the classification proposed by Vander-Zanden \& Rasmussen (1996).

\section{RESULTS}

\section{Fishes}

The highest $\delta^{13} \mathrm{C}$ isotopic variability was verified for the species L. lacustris $(-25.5$ to $-33.2 \%$ ) and L. platymetopon (-22.2 to $-30.1 \%$ ) while the lowest was identified for $L$. friderici $(-26.4$ to $-30.23 \%$ ) . There was no significant difference found for the $\delta^{13} \mathrm{C}$ mean values among the species belonging to different trophic groups analyzed (ANOVA: $\mathrm{Gl}=6 ; \mathrm{F}=1.57 ; \mathrm{p}=0.17$ ). The maximum and minimum ${ }^{13} \mathrm{C}$ isotopic values revealed outliers. This happened in the case of the $\delta^{13} \mathrm{C}$ minimum value for $L$. lacustris $(-33.1)$ and the maximum value for L platymetopon (-22.2).

For the $\delta^{15} \mathrm{~N}$ mean values, there were significant differences among the species analyzed (ANOVA: $\mathrm{Gl}=6 ; \mathrm{F}=13.96 ; \mathrm{p}<0.05$ ). The highest variability was found for $S$. marginatus (9.7 to $16.4 \%$ ), I. labrosus (9.1 to $15.4 \%$ ), S. borellii (6.06 to $12.44 \%$ ), and A. osteomystax (9.7 to $15.1 \%$ ). Lowest variability was found for L. platymetopon (7.0 to $8.2 \%$ ) and L. friderici (7.41 to $9.18 \%$ ).

\section{Primary producers}

The phytoplanktonic algae presented the most depleted $\delta^{13} \mathrm{C}$ values $(-35.6 \pm 2.33 \%$ ) compared to the other $\mathrm{C}_{3}$ plant groups, while the $\mathrm{C}_{4}$ aquatic macrophytes were the most enriched $(-12.6 \pm 0.62 \%$ ) . The riparian vegetation, $\mathrm{C}_{3}$ aquatic macrophytes, and periphyton showed intermediate values: $-29.5 \pm$ $0.87 \%$ o, $-28.9 \pm 1.21 \%$ o, $-28.7 \pm 2.70 \%$ o, respectively. The nitrogen isotopic mean values were: riparian vegetation, $1.3 \pm 1.31 \%$; $\mathrm{C}_{3}$ and $\mathrm{C}_{4}$ aquatic macrophytes, $1.2 \pm 2.32 \%$; periphyton, $2.7 \pm 1.38 \%$; and phytoplankton, $3.1 \pm 2.15 \%$.

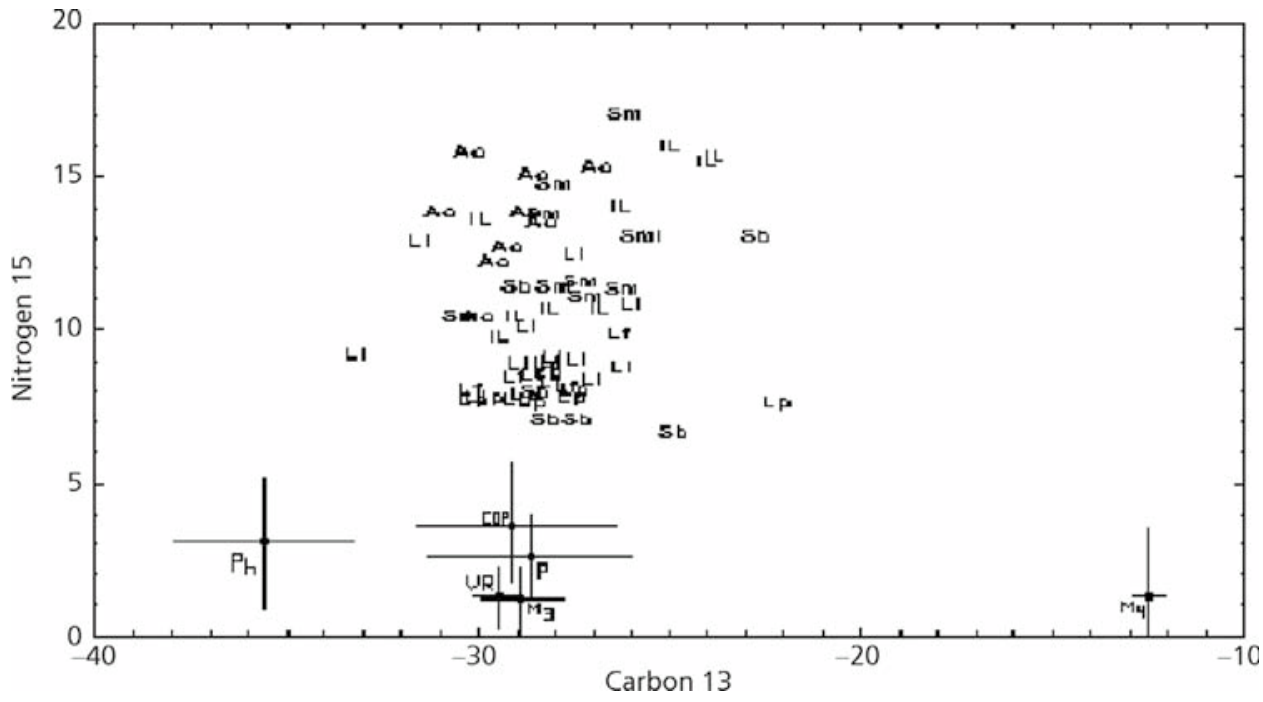

Fig. $2-\delta^{13} \mathrm{C}$ and $\delta^{15} \mathrm{~N}$ mean values and standard deviation of primary producers from the Baía subsystem $(\mathrm{Ph}=$ phytoplankton, $\mathrm{VR}=$ riparian vegetation, $\mathrm{P}=$ periphyton, $\mathrm{M}_{3}=\mathrm{C}_{3}$ aquatic macrophyte, $\mathrm{M}_{4}=\mathrm{C}_{4}$ aquatic macrophyte, $\mathrm{POC}=$ particulate organic carbon). Carbon and nitrogen isotopic values for the samples of the fishes analyzed $(\mathrm{Sm}=$ Serrasalmus marginatus, $\mathrm{Sb}=$ Schizodon borellii, $\mathrm{Lp}=$ Loricariichthys platymetopon, $\mathrm{Ll}=$ Leporinus lacustris, Ao = Auchenipterus osteomystax, $\mathrm{Il}=$ Iheringichthys labrosus, $\mathrm{Lf}=$ Leporinus friderici). 


\section{Carbon sources}

The highest carbon contributions for the fishes, regardless of the trophic group, analyzed from the Baía subsystem were provided by $\mathrm{C}_{3}$ plants, with the exception of the phytoplankton. This fact was confirmed by the overlapping isotopic values of fishes and $\mathrm{C}_{3}$ plants (Fig. 2). $\mathrm{C}_{4}$ plants contributed with a $6 \%$ minimum, for $S$. borellii and I. labrosus specie only, while the maximum contribution (between $36 \%$ and 38\%) were also recorded for these species, besides L. lacustris (Table 1).

\section{Trophic position}

The estimate of the trophic position through the $\delta^{15} \mathrm{~N}$ ranged from 2.1 (L. platymetopon) to 3.8 (A. osteomystax), while the one obtained for the diet ranged from 2.0 (S. borellii and L. platymetopon) to $3.9(S$. marginatus) (Table 2). The trophic position obtained for the dietary data was noticeably lower than that observed for the $\delta^{15} \mathrm{~N}$ analysis, except for $S$. marginatus. The mean values of trophic positions obtained by the two methods of analysis correlated significantly $\left(\mathrm{PT}_{\delta 15 \mathrm{~N}}=0.86+0.77 * \mathrm{PTM}_{\mathrm{d}} ; \mathrm{r}^{2}=0.82 ; \mathrm{p}<0.05\right)$.

TABLE 1

$\delta^{13} \mathrm{C}$ mean values ( \pm standard deviation) for the fish species from Baía subsystem and the respective minimum and maximum contributions from $\mathrm{C}_{4}$ plants.

\begin{tabular}{|l|c|c|c|}
\hline \multicolumn{1}{|c|}{ Specie } & Mean & Minimum & Maximum \\
\hline A. osteomystax & $-29.2 \pm 1.20$ & 0 & 26 \\
\hline I. labrosus & $-29.9 \pm 2.34$ & 6 & 36 \\
\hline L. lacustris & $-28.4 \pm 2.29$ & 0 & 38 \\
\hline L. platymetopon & $-28.0 \pm 2.19$ & 0 & 31 \\
\hline L. friderici & $-28.3 \pm 1.19$ & 0 & 30 \\
\hline S. borellii & $-26.8 \pm 2.46$ & 10 & 38 \\
\hline S. marginatus & $-27.6 \pm 1.42$ & 0 & 31 \\
\hline
\end{tabular}

TABLE 2

Estimate of the trophic position through dietary and $\delta^{15} \mathrm{~N}$ for the most abundant species from the Baía subsystem.

\begin{tabular}{|l|c|c|}
\hline \multicolumn{1}{|c|}{ Specie } & Dietary & $\boldsymbol{\delta}^{\mathbf{1 5}} \mathbf{N}$ \\
\hline S. marginatus & 3.9 & 3.5 \\
\hline A. osteomystax & 3.5 & 3.8 \\
\hline I. labrosus & 3.0 & 3.6 \\
\hline L. lacustris & 2.1 & 2.7 \\
\hline S. borellii & 2.0 & 2.4 \\
\hline L. friderici & 2.0 & 2.3 \\
\hline L. platymetopon & 2.0 & 2.1 \\
\hline
\end{tabular}




\section{DISCUSSION}

In aquatic animal, populations the occurence of small or no variation among individuals of the same species has been observed (Fry \& Sherr, 1984; Michener \& Schell, 1994). On the other hand, Forsberg et al. (1993) and Gu et al. (1997) found great variation in isotopic composition of fish populations. In the Baía subsystem, the population of Leporinus lacustris and Loricariichthys platymetopon presented wide isotopic variability (7.7\%o). The high food plasticity that fish species from tropical regions exhibit (Lowe McConnell, 1975) shows that individuals from the same population can ingest food from different sources, widely varying in isotopic composition (Gu et al., 1997).

Greater variability is usually observed in isotope nitrogen results rather than in those for carbon (Leite, 2000; Vander-Zanden et al., 1997). For the fish species from the Baía subsystem, this was also observed for I. labrosus (omnivorous), perhaps because of the great diversity of food items in its diet, including higher plants, detritus/sediment, besides prey from several different trophic levels. The lowest $\delta^{15} \mathrm{~N}$ variability was found for $L$. friderici (omnivorous) and L. platymetopon (detritivorous), due to the lower food plasticity, compared to that of the other species. The isotopic range found for the detritivorous species does not fit with the a generalization made by Lake et al. (2001), who assumed that direct consumption of sediment, integrated particles, and dead organisms provided by the water column, is responsible for the less clear trophic position of fishes belonging to the lowest trophic levels.

For its part, S. borellii (herbivorous) exhibited high $\delta^{15} \mathrm{~N}$ variability, although presenting low diversity of food items in its diet, which is based predominantly on higher plants $(92.2 \%)$. The primary regional group can correspond to either aquatic macrophytes or riparian vegetation. For both, Lopes (2001) observed high $\delta^{15} \mathrm{~N}$ variability in the Paraná River floodplain.

According to $\delta^{13} \mathrm{C}$ isotopic variability for the fish species analyzed, we found that the highest and lowest variation amplitudes of this isotope coincide with the variability observed for the $\mathrm{C}_{3}$ plants, specifically, riparian vegetation, $\mathrm{C}_{3}$ aquatic macrophytes, periphyton, and POC. Such overlapping complicates identifying the allochthonous or autochthonous origin of the carbon constituting the biomass of fish species of the Baía subsystem. In that subsystem, the plant portion of POC is basically constituted by $\mathrm{C}_{3}$ plants except for phytoplankton. On the contrary, Araújo-Lima et al. (1986) and Vaz et al. (1999) affirm that the particulate organic carbon is predominantly of phytoplanktonic origin.

Regardless of the trophic group, the $\mathrm{C}_{3}$ plants contribute significantly to the carbon supply of the fish species in the Baía subsystem. Forsberg et al. (1993) and Vaz et al. (1999) also recorded minor importance of the carbon provided by $\mathrm{C}_{4}$ plants in the aquatic food chains in the Amazon Basin. They identified the highest contributions of $\mathrm{C}_{4}$ plants as those of Schizodon borellii (herbivorous) and Ilheringichthys labrosus (omnivorous). In the Amazon floodplain were also found contributions from $\mathrm{C}_{4}$ plants, mainly to the herbivorous species, Schizodon fasciatus (Forsberg et al., 1993). Furthermore, Jepsen (1999) showed that Schizodon isognathus uses more than $70 \%$ of the carbon from $\mathrm{C}_{4}$ plants in the Apure River in Venezuela. Thus, essencially herbivorous species utilize most intensely carbon from $\mathrm{C}_{4}$ plants. The presence of digestive enzimes, microorganisms, or digestive system modifications allows use of $\mathrm{C}_{4}$ plants, in spite of their poor digestibility and low nutritional value (Caswell et al., 1973).

For the detritivorous Characiformes of the Amazon basin, the highest carbon contribution is provided by a food chain originating in phytoplankton (Araújo-Lima et al., 1986). The same was observed for Prochilodus lineatus in the Paraná River floodplain (Lopes, 2001). On the contrary, L. platymetopon, belonging to the Siluriformes, in the Baía subsystem and also considered detritivorous, received the highest contribution from $\mathrm{C}_{3}$ plants, with the exception of phytoplankton. This fact shows the specificity in the exploitation of a very narrow ecologic niche, confirmed in both the digestive system analysis and the size of the particles ingested by this group that feeds from the bottom (Fugi et al., 2000).

The trophic position calculated through the $\delta^{15} \mathrm{~N}$ was greater than the mean values of trophic positions obtained through the diet, contrary to the findings of Leite (2000) for fish larvae of Amazon $\left(\mathrm{PTM}_{\mathrm{d}}>\mathrm{PT}_{\delta 15 \mathrm{~N}}\right)$. Gu et al. (1997) observed that the $\delta^{15} \mathrm{~N}$ and $\delta^{13} \mathrm{C}$ isotopic results presented higher 
variability in muscles than in samples of stomach content of Oreochromis aureus. They found no significant correlation between the $\delta^{13} \mathrm{C}$ of the food content and the muscle tissue. These results, along with those of the present work, indicate that stomach content represents only food recently ingested and can include a fraction that either is not digestible or was not yet incorporated into the animal tissues. Thus, the food assimilated and incorporated into the muscle tissue can present distinct isotopic values from those of the gastric content. On the other hand, evaluating of the trophic position through the $\delta^{15} \mathrm{~N}$ shows no influence of the trophic position of the food item, but depends on the estimate of $\delta^{15} \mathrm{~N}$ of primary producers and on constant isotopic fractionation.

The determination coeficient $\left(\mathrm{r}^{2}\right)$ obtained among the trophic positions, estimated through the diet and $\delta^{15} \mathrm{~N}$, was superior to that found by Leite (2000) and Vander-Zander et al. (1997), indicating that $82 \%$ of the diet was incorporated into the muscle tissue. The trophic position obtained, from either diet or $\delta^{15} \mathrm{~N}$, revealed that L. lacustris, L. platymetopon, $L$. friderici, and $S$. borellii were characterized as primary consumers. On the other hand, A. osteomystax, S. marginatus, and I. labrosus occupied the highest trophic levels, as shown by the calculation of trophic position using $\delta^{15} \mathrm{~N}$. With the dietary data, $S$. marginatus had a superior trophic level to that of $A$. osteomystax, indicating that although both species ingest a wide variety of preys belonging to several trophic levels, proteic utilization of the carnivorous specie may be superior to that of the piscivorous specie.

Considering the high isotopic variability observed for the fish species of this subsystem, changes in the trophic hierarchy dependent on the environment are expected. Species like $L$. friderici have the capability to change their trophic position in the food chain, in response to local circumstances and dietary ontogenetic variations (Benedito-Cecilio et al., subm.). Thus, food chain dynamic characteristics, such as seasonal alterations in trophic interactions and participation in the microbial loop, suggest that a species' trophic positions are likely to be dynamic, thus precluding generalizations about food strategies of this fish species which would extend to other subsystems of the Paraná River floodplain.
The fish species biomass of the trophic groups in the Baía subsystem is maintained by the same $\mathrm{C}_{3}$ carbon sources. The high isotopic amplitude exhibited by the analyzed species indicates tolerance to the environmental changes being imposed by the Paraná River basin dams. However, the effects of irregular oscillations of the water level resulting from the hydroelectric plant operation on primary producer biomass, and also over rainy season patterns, responsible for allochthonous nutrient input into the aquatic communities, are unknown. Lack of such information compromises the management and, consequently, sustainability of fish species biomass in the system.

The results of methodologies used in trophic position identification do not present differences, nevertheless the correlation between both although high indicates that there is still a difference between ingested food and that assimilated. In order to more precisely characterize the food web, the isotopic variability of other biological compartments, such as macroinvertebrates, must be investigated.

Acknowledgments - We are grateful to the post-graduate course in Ecologia de Ambientes Aquáticos Continentais and to the CNPq for financial support; to the field team PELD/2000; to Dr. Marcelo Zacharias Moreira (CENA/USP) for help in isotopic determinations; and to Alexandre Leandro Pereira and Célia de Almeida Lopes for help in the field.

\section{REFERENCES}

ARAÚJO-LIMA, C. A. R., FORSBERG, B. R., VICTORIA, R. \& MARTINELLI, D., 1986, Energy sources for detritivorous fishes in the Amazon. Science, 234: 1256-1258.

BENEDITO-CECILIO, E., PEREIRA, A. L. \& SAKURAGUI, C. M., submetido, Effects of size on energy acquisition in Leporinus friderici (Characiformes: Anostomidae) from Corumbá Reservoir, Brazil.

CASWELL, H., REED, F., STEPHENSON, S. N. \& WERNER, P. A., 1973, Photosynthetic pathways and selective herbivory: a hypothesis. Am. Nat., 107: 465-480.

DE NIRO, M. \& EPSTEIN, S., 1978, Influence of diet on the distribution of carbon isotopes in animals. Geochim. Cosmoch. Acta, 42: 495-506.

DENIRO, M. \& EPSTEIN, S., 1981, Influence of diet on the distribution of nitrogen isotopes in animals. Geochim. Cosmoch. Acta, 42: 495-506.

FORSBERG, B. R., ARAUJO-LIMA, C. A. R. M. MARTINELLI, L. A., VICTORIA, R. L. \& BONASSI, J. A., 1993, Autotrophic Carbon Sources for Fish of the Central Amazon. Ecology, 74: 643-652. 
FRY, B. \& ARNOLD, C., 1982, Rapid ${ }^{13} \mathrm{C} /{ }^{12} \mathrm{C}$ Turnover during growth of brown shrimp (Penaeus aztecus). Oecologia, 54: 200-204

FRY, B. \& SHERR, E. B., 1984, $\delta^{13}$ C measurements as indicators of carbon flow in marine and freshwater ecosystems. Contrib. Mar. Sci., 27: 13-47.

FRY, B., 1988, Food web structure on Georges Bank from stable C, N, and S isotopic composition. Limnol. Oceanogr., 33: $1182-1190$

FUGI, R., AGOSTINHO, A. A. \& HAHN, N. S., 2000, Trophic Morphology of five benthic-feeding fish species of a tropical floodplain. Rev. Brasil. Biol., 61(1): 27-33.

GU, B., SCHELSKE, C. L. \& HOYER, M. V., 1997, Intrapopulation feeding diversity in blue tilapia: evidence from stable-isotope analyses. Ecology, 78: 2263-2266.

JENNINGS, S., REÑONES, O., MORALES-NIN, B., POLUNIN, N. V. V., MORANTA, J. \& COLL, J., 1997, Spatial variation in the ${ }^{15} \mathrm{~N}$ and ${ }^{13} \mathrm{C}$ stable isotope composition of plants, invertebrates and fishes on Mediterranean reefs: implications for the study of trophic pathways. Mar. Ecol. Prog. Ser., 146: 109-116.

JEPSEN, D. B., 1999, Analysis of trophic pathways in freshwater ecosystems using stable isotope signatures. Dissertation Ph.D. Textas A \& M University, 148p.

LAKE, J. L., MCKINNEY, R. A., OSTERMAN, F. A., PRUELL, R. J., KIDDON, J., RYBA, S. A. \& LIBBY, A. D., 2001 Stable nitrogen isotopes as indicators of anthropogenic activities in small freshwater systems. Can. J. Fish. Aquat. Sci., 58: 870-878.

LEITE, G. R., 2000, Fontes de energia utilizadas pelas larvas de peixes no rio Solimões/Amazonas e suas áreas inundáveis. Tese de Doutorado em Ciências Biológicas, Universidade do Amazonas, 115p.

LOPES, A. C., 2001, Variabilidade de $\delta^{13} \mathrm{C}$ e de $\delta^{15} \mathrm{~N}$ em fontes alóctones e autóctones para cadeias alimentares na bacia do rio Paraná, entre a foz dos rios Paranapanema e Iguaçu. Dissertação de Mestrado em Ecologia de Ambientes Aquáticos Continentais, Departamento de Biologia, Universidade Estadual de Maringá, 15p.
LOWE McCONNELL, R. H., 1975, Fish communities in tropical freshwaters. Logman, New York, 284p.

MAGNUSSON, W. E., ARAUJO, M. C., CINTRA, R., LIMA, A. P., MARTINELli, L. A., SANAIOTTI, T. M., VASCONCELOS, H. L. \& VICTORIA, R. L., 1999, Contributions of $\mathrm{C}_{3}$ and $\mathrm{C}_{4}$ plants to higher trophic levels in an Amazonian savanna. Oecologia, 119: 91-96.

MICHENER, R. H. \& SCHELL, D. M., 1994, Stable isotope ratios as tracers in marine aquatic food webs. In: H. Lajtha \& R. Michener H. (ed.), Stable isotopes in ecology and environmental science. Blackwell Scientific, Oxford, pp. 138-157.

MINAGAWA, M. \& WADA, E., 1984, Stepwise enrichment of ${ }^{15} \mathrm{~N}$ along food chains: further evidence and the relation between $\delta^{15} \mathrm{~N}$ and animal age. Geochim. Cosmoch. Acta, 48: $1135-1140$

PERETTI, D., 2001, Estrutura trófica da comunidade ictiofaunística de cinco lagoas permanentes da planície de inundação do alto rio Paraná, Brasil. Maringá, Dissertação de Mestrado em Ecologia de Ambientes Aquáticos Continentais, Universidade Estadual de Maringá, 44p.

THOMAS, C. J. \& CAHOON, L. B., 1993, Stable isotope analyses differentiate between different trophic pathways supporting rocky-reef fishes. Mar. Ecol. Prog. Ser., 95: 19-24.

VANDER-ZANDEN, M. J., CABANA, G. \& RASMUSSEN, J. B., 1997, Comparing trophic position of freshwater fish calculated using stable nitrogen isotope ratios $\left(\delta^{15} \mathrm{~N}\right)$ and literature dietary data. Can. J. Fish. Aquat. Sci., 54: 11421158

VANDER-ZANDEN, M. J. \& RASMUSSEN, J. B., 1996, A trophic position model of pelagic food webs: impact on contaminant biomagnification in lake trout. Ecol. Monogr., 66: $451-477$

VAZ, M. M., PETRERE Jr. M., MARTINELLI, L. A. \& MOZETO, A. A., 1999, The dietary regime of detritivorous fish from the River Jacaré-Pepira, Brasil. Fish. Maneg. Ecol., 6: 121-132. 